\title{
An Irrigation Scheduling Model for Summer Squash
}

\author{
Doyle A. Smittle, W. Lamar Dickens, and M. Jane Hayes \\ Department of Horticulture, University of Georgia, Tifton, GA 31794 \\ Additional index words. pan evaporation, soil water tension, nitrogen fertilization, Cucurbita pepo
}

\begin{abstract}
An irrigation scheduling model for summer squash (Cucurbita pepo $\mathbf{L}$.) was developed and validated during 1986, 1987, and 1989. The model is represented by the equation: 12.7(i -4$) \times 0.5 \mathrm{ASW}=\mathrm{D}_{\mathrm{i}-1}+[\mathrm{E}(0.14+$ $0.015)$ - $P$ - $I]_{i}$, where crop age in days is $i$; effective root depth is $12.7(i-4)$ with a maximum of $381 \mathrm{~mm}$; usable water (cubic millimeter per cubic millimeter of soil) is $0.5 \mathrm{ASW}$, deficit on the previous day is $\mathrm{D}_{\mathrm{i}-1}$; evapotranspiration is pan evaporation (E) times $0.14+\mathbf{0 . 0 1 5 i}$; rainfall (in millimeters) is P; and irrigation (in millimeters) is $I$. The model was validated during the three years using a line-source irrigation system with irrigation depths ranging from $5 \%$ to $160 \%$ of the model rates. Nitrogen rates were $50 \%, 100 \%$, and $150 \%$ of the recommended rate. Marketable fruit yields increased as the irrigation depths increased up to the model rate then decreased with greater water application depths. Marketable fruit yields increased as the $N$ rate increased in 1987 and 1989, but yields were similar at all $\mathbf{N}$ rates in 1986. The shelf life of marketable fruits was not influenced by irrigation or $\mathrm{N}$ rates.
\end{abstract}

Summer squash has been classified as moderately sensitive to water stress. The blossom and fruit development stage of growth has been classified as more sensitive than the preblossom stage of growth (Bruce et al., 1980). Most researchers agree that irrigation should be applied before 50\% of the available soil water has been depleted from the root zone (Bruce et al., 1980; Hansen et al., 1980; Smittle and Threadgill, 1982; Stansell and Smittle, 1989; Vittum and Flocker, 1967). However, Portas (1968) noted that the root zone was not uniformly permeated by roots and that the root zone was a dynamic rather than a static system. Therefore, the fraction of the available soil water depletion necessary to cause a yield reduction depends on the depth at which soil water is measured and the rooting depth of the crop (Bruce et al., 1980). The root system and water extraction zone generally expand at the rate of 12 to $15 \mathrm{~mm} \cdot \mathrm{day}^{-1}$ under good growing conditions (Hansen et al., 1980). Soils in the southeastern United States normally do not allow crop roots to penetrate as deeply as do soils in the western states (Bruce et al., 1980). 'Therefore, determination of both the effective root volume and the soil water-holding capacity, and crop water use is essential to the development of an effective irrigation program.

Scheduling of irrigations can be based on soil, plant, or climatological measurements. The advantages and disadvantages of each method have been reviewed by Haise and Hagan (1967), Hansen et al. (1980), Stegman et al. (1980), and Vittum and Flocker (1967). The availability of climatological data and the ease of their use are important criteria in the selection of an irrigation scheduling method. Climate-based methods of estimating evapotranspiration (ET) have been used in irrigation scheduling models (Haise and Hagan, 1967; Hansen et al., 1980; Stegman et al., 1980), but the climate-based methods have often required calibration for the crop and local climatic conditions. Measurements of air temperature, air movement, solar radiation, and relative humidity are often used to estimate ET (Haise and Hagan, 1967). Pan evaporation is inherently responsive to these conditions and has been used to estimate ET (Jensen and

Received for publication 20 Dec. 1991. Accepted for publication 18 May 1992. Supported by state and Hatch Act funds allocated to the Georgia Agricultural Experiment Stations. The cost of publishing this paper was defrayed in part by the payment of page charges. Under postal regulations, this paper therefore must be hereby marked advertisement solely to indicate this fact.
Middleton, 1970; Smittle et al., 1990; Stansell and Smittle, 1989).

The research described in this paper consists of the development and validation of an irrigation scheduling model for summer squash. The model uses pan evaporation modified by a continuously variable crop factor function to estimate ET and a dynamic root-depth function to schedule irrigations.

\section{Materials and Methods}

Model development. The proposed irrigation scheduling model uses the water balance technique described by Stegman et al. (1980). The water balance technique for irrigation scheduling simply states that water in the amount of the cumulative soil water deficit is applied when the cumulative deficit equals the allowable soil water deficit. The water balance model is computed as: $A_{i}=D_{i-1}+(E T-P-I)_{i}$, where $A_{i}$ is the allowable soil water deficit (in millimeters) on day $i ; D_{i-1}$ is the soil water deficit on day $\mathrm{i}-1$; ET is the estimated evapotranspiration (in millimeters) on day $\mathrm{i}$; $\mathrm{P}$ is the precipitation (in millimeters) on day $\mathrm{i}$; and $\mathrm{I}$ is the irrigation (in millimeters) on day $i$.

The proposed irrigation scheduling model for squash, after seedling emergence, can be represented by the equation: $12.7(\mathrm{i}$ - 4) $\times 0.5 \mathrm{ASW}=\mathrm{D}_{\mathrm{i}-1}+[\mathrm{E}(0.14+0.15 \mathrm{i})-\mathrm{P}-\mathrm{I}]_{\mathrm{i}}$, where ASW is available soil water (in millimeters) and $\mathrm{E}$ is pan evaporation (in millimeters).

The allowable soil water depletion is a function of the effective root depth, the water retention characteristics of the soil, and the sensitivity of the crop to water stress. For the root-depth portion of the model, we assumed a seeding depth of $25.4 \mathrm{~mm}$, 6 days for significant radicle emergence, and a root growth rate of $12.7 \mathrm{~mm} \cdot \mathrm{day}^{-1}$. Root depth after seedling emergence can be computed as: $12.7\left(_{i-4}\right)$.

Water extraction by squash is restricted to the upper 380 to $400 \mathrm{~mm}$ of the soil profile in Coastal Plain soils of the southeastern United States (Bruce et al., 1980; Smittle and Williamson, 1977; Stansell and Smittle, 1989). Therefore, a maximum root depth of $380 \mathrm{~mm}$ was used. Root depth may exceed 380 $\mathrm{mm}$ in deep soils (Jensen and Middleton, 1970) or may be less than that if tillage pans or other soil factors restrict root growth (Smittle and Williamson, 1977).

The water retention characteristics of soils vary from 0.02 to $0.23 \mathrm{~mm}^{3}$ per cubic millimeter of root depth among soil texture 
classes, with ASW capacities generally increasing as soil particle size decreases (Hansen et al., 1980; Stegman et al., 1980). The upper retention limit (field capacity) is normally measured after 2 to 4 days of drainage. Water use by crops at soil water contents above field capacity is substantial with frequent irrigation (Hansen et al., 1980); therefore, an ASW depletion of $50 \%$ was allowed. The ASW of the Tifton loamy sand soil (Plinthitic Paleudult; fine loamy, siliceous, thermic) used for these tests was $0.1 \mathrm{~mm}$ per millimeter of soil depth. The allowable deficit during root-zone expansion can be computed as: $12.7\left({ }_{i-4}\right) \times{ }_{0.5} \mathrm{~A} \mathrm{~S} \mathrm{~W}$.

Daily water use (ET) was computed using the procedure of Jensen and Middleton (1970). The crop factor regression reported by Stansell and Smittle (1989) for spring-planted summer squash was used to estimate ET from pan evaporation (E) data where: $\mathrm{ET}=\mathrm{E}(0.14+0.015 \mathrm{i})$. Daily crop factor values computed by this equation ranged from 0.16 to 1.04 for the 60 -day growing season of the crop.

For computational ease and record keeping, this equation can be solved in a tabular format where column headings are age, root depth, date, pan evaporation, crop factor, daily deficit, cumulative deficit, allowable deficit, rainfall, and irrigation, respectively. An example of the tabular format of the irrigation scheduling model for summer squash 15 to 25 days after planting (DAP) in 1989 is shown in Table 1. Values for root depth, crop factor, and allowable deficit are computed by age and tabulated. The date and pan evaporation (in millimeters) values are entered. Pan evaporation is multiplied by the daily crop factor value, and that product is entered in the daily water use column. Daily water use is accumulated, and rainfall is recorded and subtracted until the cumulative deficit approximates the allowable deficit. On that date, irrigation equal to the cumulative water use is applied.

Model validation. A line-source irrigation system as described by Bauder et al. (1975) and Hanks et al. (1976) was used to verify the summer squash irrigation scheduling model in 1986, 1987, and 1989. The system consisted of a single line of closely spaced $(6.1 \mathrm{~m})$ sprinklers to provide uniform water application parallel to the irrigation line and continuously decreasing water application with increasing distance from the irrigation line.

General cultural practices were the same for 1986, 1987, 1988, and 1989. A rye (Secale cereale L.) cover crop was incorporated to a depth of $150 \mathrm{~mm}$ before moldboard plowing to a depth of $300 \mathrm{~mm}$. Squash and muskmelon were grown on alternate beds in 1986 and 1987. The entire field was seeded to squash in 1988 and 1989 . Fertilizer at $28 \mathrm{~N}-24 \mathrm{P}-170 \mathrm{~K}\left(\mathrm{~kg} \cdot \mathrm{ha}^{-1}\right)$ and ethyl(4-(methylthio)-m-toyl isopropylphosphoramidate (phenamiphos, a preplant nematicide) at $6.7 \mathrm{~kg}$ a.i./ha were incorporated to a depth of $100 \mathrm{~mm}$ immediately before seeding. 'Dixie' yellow summer squash was seeded at $30-\mathrm{cm}$ spacing in rows spaced $0.9 \mathrm{~m}$ apart on $1.8-\mathrm{m}$ beds. Planting dates were 25 Mar. 1986, 23 Mar. 1987, and 29 Mar. 1989. Immediately after seeding, 3 amino-2,5 dichlorobenzoic acid (chloroamiben, a preemergence herbicide) at $2.2 \mathrm{~kg}$ a.i./ha was applied and incorporated with $13 \mathrm{~mm}$ of irrigation. The $\mathrm{N}$ sidedress was split, with one-half applied at 3 and 5 weeks after seeding. Sidedress $\mathrm{N}$ rates were 18,50 , and. $82 \mathrm{~kg} \cdot \mathrm{ha}^{-1}$ at each application to provide total $\mathrm{N}$ rates that were $50 \%, 100 \%$, and $150 \%$ of the recommended rate of 90 to $135 \mathrm{~kg} \cdot \mathrm{ha}^{-1}$ (Plank, 1989).

The design was a split block with three $\mathrm{N}$ rates and seven irrigation rates. Plots were replicated twice on each side of the irrigation line. The $\mathrm{N}$ plots were $6.1 \mathrm{x} 14.6 \mathrm{~m}$ with seven irrigation rate plots within each $\mathrm{N}$ plot. The irrigation rate plots were $6.1 \mathrm{~m}$ of a $1.8-\mathrm{m}$-wide bed. The beds were parallel to the irrigation line, and irrigation rates decreased as distance from the irrigation line increased. The irrigation line was placed on a central guard bed, and the third bed from the line received irrigation according to the model. Depths of water applied to each bed on both sides of the irrigation line were measured after each irrigation. Soil water tensions at 150, 300, and $460 \mathrm{~mm}$ in each bed on both sides of the irrigation line were monitored with cylindrical gypsum block sensors using a Delmhorst Model KS-2 meter (Delmhorst Instrument Co., Boonton, N.J.).

Table 1. Tabular format of the summer squash irrigation model: $12.7(\mathrm{i}-4) \times 0.5 \mathrm{ASW}=$

\begin{tabular}{|c|c|c|c|c|c|c|c|c|c|}
\hline $\begin{array}{l}\text { Age } \\
\text { DAP) } \\
\end{array}$ & $\begin{array}{l}\text { Root } \\
\text { depth } \\
(\mathrm{mm})\end{array}$ & $\begin{array}{c}\text { Date } \\
\text { (April) }\end{array}$ & $\begin{array}{c}\text { Pan } \\
\text { evaporation } \\
(\mathrm{mm}) \\
\end{array}$ & $\begin{array}{l}\text { Crop } \\
\text { factor }\end{array}$ & $\begin{array}{c}\text { Daily } \\
\text { use } \\
(\mathrm{mm}) \\
\end{array}$ & $\begin{array}{c}\text { Cumulative } \\
\text { use } \\
(\mathrm{mm})\end{array}$ & $\begin{array}{c}\text { Allowable } \\
\text { use } \\
\text { (mm) }\end{array}$ & $\begin{array}{c}\text { Irrigation } \\
(\mathrm{mm})\end{array}$ & $\begin{array}{l}\text { Rain } \\
(\mathrm{mm})\end{array}$ \\
\hline 15 & 14.0 & 13 & 5.6 & 0.37 & 2.0 & 3.3 & 7.1 & & \\
\hline 16 & 15.2 & 14 & 5.6 & 0.38 & 2.0 & 5.5 & 7.6 & & \\
\hline 17 & 16.5 & 15 & 3.3 & 0.40 & 1.3 & 6.8 & 8.4 & & \\
\hline 18 & 17.8 & 16 & 2.5 & 0.41 & 1.0 & 0.0 & 8.9 & & 15 \\
\hline 19 & 19.1 & 17 & 7.6 & 0.43 & 3.3 & 3.3 & 9.7 & & \\
\hline 20 & 20.3 & 18 & 5.1 & 0.44 & 2.3 & 5.6 & 10.2 & & \\
\hline 21 & 21.5 & 19 & 4.6 & 0.46 & 2.0 & 7.6 & 10.9 & & \\
\hline 22 & 22.9 & 20 & 6.1 & 0.47 & 2.8 & 10.4 & 11.4 & & \\
\hline 23 & 24.1 & 21 & 3.3 & 0.49 & 1.3 & 11.7 & 12.2 & & \\
\hline 24 & 25.4 & 22 & 4.3 & 0.50 & 2.3 & 14.0 & 12.7 & 14 & \\
\hline 25 & 26.7 & 23 & 4.6 & 0.52 & 2.3 & 2.3 & 13.5 & & \\
\hline
\end{tabular}

${ }^{3}$ To operate the model, values for root depth $[0.5(\mathrm{i}-4)]$, crop factor $(0.14+0.015 \mathrm{i})$, and allowable use (root depth $\times 0.5 \mathrm{ASW}$ ) are calculated as a function of age (i). Date and pan evaporation are recorded. Data for pan evaporation are multiplied by the crop factor to estimate daily water use. Daily use is added to the cumulative use. Data for irrigation and rainfall are subtracted from the cumulative use. Irrigation, in the amount of the cumulative use, is applied when cumulative use approximates the allowable use.

${ }^{y} \mathrm{ASW}=$ available soil water; $\mathrm{D}=$ soil water deficit; $\mathrm{E}=$ pan evaporation; $\mathrm{P}=$ precipitation; $\mathrm{I}=$ irrigation (in millimeters); DAP $=$ days after planting.

${ }^{x}$ Summer squash planted on Tifton loamy sand soil $\left(0.1 \mathrm{~mm}^{3}\right.$ per cubic millimeter of available soil water). 
Table 2. Water application rates to 'Dixie' summer squash.

\begin{tabular}{|c|c|c|c|c|c|c|}
\hline \multirow{2}{*}{$\begin{array}{l}\text { Irrigation } \\
\text { rate }^{z} \\
\end{array}$} & \multicolumn{3}{|c|}{ Water applied $(\mathrm{mm})$} & \multicolumn{3}{|c|}{ Percentage of model } \\
\hline & 1986 & 1987 & 1989 & 1986 & 1987 & 1989 \\
\hline 1 & 318 & 226 & 323 & 143 & 142 & 160 \\
\hline 2 & --- & --- & 256 & --- & --- & 127 \\
\hline $3^{y}$ & 223 & 159 & 202 & 100 & 100 & 100 \\
\hline 4 & --- & --- & 173 & --- & -- & 86 \\
\hline 5 & 140 & 95 & 141 & 63 & 60 & 70 \\
\hline 6 & --- & --- & 101 & -- & -- & 50 \\
\hline 7 & 15 & 10 & 10 & 7 & 6 & 5 \\
\hline Rainfall & 165 & 210 & 135 & & & \\
\hline
\end{tabular}

${ }^{2}$ All plots received an additional $13 \mathrm{~mm}$ of irrigation after seeding. 'Irrigation rate 3 was determined by the irrigation scheduling model. Other rates reflect water application gradients produced by the linesource irrigation system.

Harvests of 4.2- $\mathrm{m}^{2}$ yield plots began on 7 May 1986, 13 May 1987, 20 May 1988, and 15 May 1989. Squash fruits having a diameter $>3 \mathrm{~cm}$ were harvested three times per week for 3 weeks. Fruits were graded, and the number and weight of total and marketable fruit were determined. Data for accumulated number of fruit and weight of total and marketable yields and average fruit weights were used for statistical analyses. Fruit samples at the fourth harvest, made 54 DAP in 1989, were used for shelf-life evaluation, which consisted of determining the number of marketable fruit from a lo-fruit sample that remained in marketable condition after 1 week at $5 \mathrm{C}$, followed by 2 days at $1.5 \mathrm{C}$

Data were analyzed by regression analyses using the general linear models procedure of SAS (1982).

\section{Results and Discussion}

Squash of the 1988 experiment were destroyed by hail after 2 weeks of harvest; therefore, the 1988 results are not presented. Yield and soil water tension results before the 3rd week of harvest in 1988 were similar to 1989 results.
The model called for 10 irrigations in 1986 and 1989 with total water depths of 223 and $202 \mathrm{~mm}$, respectively (Table 2). In 1987 more rainfall resulted in the need for only seven irrigations with $159 \mathrm{~mm}$ of water. The line-source irrigation system produced water application depths ranging from $5 \%$ to $160 \%$ of the model rate.

Soil water tension data showed similar patterns before irrigations each year. Therefore, only 1989 data are presented (Table 3). The allowable soil water deficit for the Tifton soil increased $3.8 \mathrm{~mm} \cdot \mathrm{day}^{-1}$ until the maximum allowable deficit of $19 \mathrm{~mm}$ was attained 34 DAP.

The cumulative soil water deficits at the time irrigations were applied are the irrigation depths for the model rate shown in Table 3. If the irrigation model functions properly, the soil water tension for $100 \%$ of the model rate should be $25 \mathrm{kPa}$ when irrigations with $19 \mathrm{~mm}$ of water were applied after 34 DAP. The soil water tensions were near $25 \mathrm{kPa}$ at each irrigation when $\approx 19 \mathrm{~mm}$ of irrigation was applied, but the soil water tension substantially exceeded $25 \mathrm{kPa}$ when the cumulative deficit exceeded the allowable deficit by $5 \mathrm{~mm} 40$ DAP. At the time of irrigation applications, soil water tensions with irrigation at $127 \%$ and $160 \%$ of the model rate were about the same as when irrigation was applied at the model rate. These results would be expected if water application at the model rate recharged the soil profile and if water applications in excess of the model rate percolated below the $300 \mathrm{~mm}$ measurement depth. Soil water tensions generally exceeded $25 \mathrm{kPa}$ when the water application rate was $<100 \%$ of the model rate. The soil water tensions at irrigation increased as the water rate decreased. These results indicate that the model effectively scheduled irrigations for summer squash to meet maximum yield conditions established earlier (Stansell and Smittle, 1989).

In 1986 the marketable fruit yield increased as the irrigation rate increased up to the model rate; it then changed very little when water at $143 \%$ of the model rate was applied (Table 4). Marketable fruit yields also increased as the irrigation rate increased up to the model rate in 1987 and 1989, but water ap-

Table 3. Rainfall and irrigation amounts and soil water tensions during growth of 'Dixie' summer squash in 1989.

\begin{tabular}{|c|c|c|c|c|c|c|c|c|c|}
\hline \multirow[b]{2}{*}{ DAP } & \multicolumn{2}{|c|}{$\begin{array}{l}\text { Water intercepted } \\
(\mathrm{mm})\end{array}$} & \multicolumn{7}{|c|}{ Irrigation rate (\% of model) } \\
\hline & Rainfall & Irrigation $^{2}$ & 160 & 127 & 100 & 86 & 70 & 50 & 5 \\
\hline & & & \multicolumn{7}{|c|}{ Soil water tension $(k P a)^{y}$} \\
\hline 2 & 7 & --- & --- & --- & --- & --- & -.. & --- & -- \\
\hline 7 & -.- & 7 & -.- & -- & --- & --- & -.. & -.. & --- \\
\hline 10 & $-\cdots$ & 5 & $\ldots$ & --- & --- & --. & --- & --. & -- \\
\hline 13 & 51 & $\cdots$ & -.- & -.- & --- & --- & --- & $-\cdots$ &.-- \\
\hline 18 & 15 & --- & -.- & --- & ..- & --. & --- & --- & --- \\
\hline 24 & --- & 14 & 20 & 21 & 19 & 19 & 20 & 21 & 18 \\
\hline 29 & --- & 17 &.- & ... & --- & -.. & -- & -- & --. \\
\hline 34 & 44 & -.- & 18 & 18 & 18 & 18 & 19 & 20 & 18 \\
\hline 38 & 9 & ... & ... & -.-- & ... & --- & ... & --- & -.. \\
\hline 40 & -- & 24 & 28 & 52 & 49 & 60 & 71 & 54 & 74 \\
\hline 42 & 36 & $-\ldots$ & 23 & 24 & 22 & 23 & 22 & 24 & 22 \\
\hline 47 & --- & 20 & 25 & 26 & 24 & 33 & 33 & 36 & 41 \\
\hline 51 & --- & 22 & 23 & 30 & 28 & 73 & 104 & 127 & 215 \\
\hline 55 & 3 & -.. & 25 & 27 & 24 & 23 & 36 & 79 & 400 \\
\hline 57 & --- & 21 & 23 & 24 & 23 & 24 & 44 & 90 & 600 \\
\hline 60 & --- & 21 & 22 & 28 & 26 & 28 & 44 & 64 & -.. \\
\hline 63 & -.. & 22 & 22 & 23 & 24 & 32 & 66 & 127 & ... \\
\hline
\end{tabular}

Irrigation depth applied by the model rate $(100 \%)$

Soil water tension is average of sensors at 15 and $30-\mathrm{cm}$ depths. 
Table 4. Yield responses of 'Dixie' summer squash to irrigation rates.

\begin{tabular}{lccc}
\hline \hline \multirow{2}{*}{$\begin{array}{l}\text { Irrigation } \\
\text { rate }^{\mathbf{z}}\end{array}$} & \multicolumn{3}{c}{ Marketable fruit yield $\left(\mathrm{t} \cdot \mathrm{ha}^{-1}\right)$} \\
\cline { 2 - 4 } 1 & 1986 & 1987 & 1989 \\
\hline 2 & 35.0 & 18.5 & 29.4 \\
$3^{\mathrm{z}}$ & --- & --- & 30.6 \\
4 & 35.8 & 28.2 & 32.9 \\
5 &.--- & 30.7 \\
6 & 24.2 & 24.4 & 28.6 \\
7 & --- & --- & 25.4 \\
Significance & 9.9 & 16.5 & 18.4 \\
\hline
\end{tabular}

Irrigation rate 3 was determined by the irrigation scheduling model. Rates 2 and 1 represent progressively greater water applications, and rates 4-7 represent progressively smaller water applications by a linesource irrigation system (see Table 1).

'Linear $\left(\mathrm{L}^{* *}\right)$ and quadratic $\left(\mathrm{Q}^{* *}\right)$ effects if irrigation rate significant at $P=0.01$.

Table 5. Effect of $\mathrm{N}$ rate on yield of marketable 'Dixie' squash fruit.

\begin{tabular}{lccc}
\hline \hline Nitrogen & \multicolumn{3}{c}{ Marketable fruit yield (t.ha- $\left.{ }^{-1}\right)$} \\
\cline { 2 - 4 } rate $^{z}$ & 1986 & 1987 & 1989 \\
\hline 50 & 27.1 & 20.0 & 27.0 \\
100 & 28.3 & 20.6 & 27.0 \\
150 & 27.3 & 25.1 & 29.8 \\
Significance & NS & $\mathrm{L}^{*} \mathrm{O}^{* *}$ & $\mathrm{O}^{*}$ \\
\hline
\end{tabular}

${ }^{7}$ Nitrogen rates represent percentage of the kilograms per hectare recommended for Georgia.

$*, * *,{ }^{\text {NS }}$ Linear $(\mathrm{L})$ and quadratic $(\mathrm{Q})$ effects of $\mathrm{N}$ rate significant at $P$ $=0.01$ and 0.05 or nonsignificant, respectively.

plications higher than the model rate reduced yields these years. Plants receiving $142 \%$ of the model rate in 1987 and $127 \%$ and $160 \%$ of the model rate in 1989 showed $\mathrm{N}$ deficiency symptoms during the 2 nd week of harvest. Leaching of $\mathrm{N}$ below the root system may have been a major contributor to the lower yields with these excessive water applications. Irrigation rates did not influence the percentage of marketable fruit at harvest, and, thus, total yield results are not presented. These results show that the model maximized fruit yields as well as maintained the soil water tensions at the desired levels.

Shelf-life evaluations showed that $92 \%$ of the marketable squash fruits at harvest were still marketable after 1 week at $5 \mathrm{C}$ followed by 2 days at $15 \mathrm{C}$. Shelf life of the squash was not influenced by the irrigation rates or $\mathrm{N}$ fertilization rates of the 1989 experiment.

Marketable fruit yields were not influenced by $\mathrm{N}$ rates in 1986 (Table 5). Marketable fruit yields in 1987 and 1989 were similar with $\mathrm{N}$ rates at $50 \%$ and $100 \%$ of the $128 \mathrm{~kg} \cdot \mathrm{ha}^{-1}$ recommended for Georgia; however, marketable fruit yield increased when the total $\mathrm{N}$ application was $150 \%$ of the recommended rate. Similar yield responses to variations of irrigation and $\mathrm{N}$ rates were observed earlier for snap bean (Phaseolus vulgaris L.) (Smittle et al., 1990). A significant irrigation rate $\times \mathrm{N}$ rate interaction occurred for marketable snap bean pod yield, but this interaction for marketable squash yields was not significant in 1986, 1987, or 1989.

Results of these experiments show that the frequency and depth of irrigation for yellow summer squash can be effectively scheduled with the irrigation model. The model-based irrigation program maximized marketable fruit yields irrespective of $\mathrm{N}$ rates in 1986, 1987, 1988, and 1989. Application of $\mathrm{N}$ at $50 \%$ of the recommended rate did not influence marketable fruit yields, while an increase of the $\mathrm{N}$ rate to $150 \%$ of the recommended rate resulted in small yield increases.

\section{Literature Cited}

Bauder, J.W., R.J. Hanks, and D.W. Jones. 1975. Crop production function determinations as influenced by irrigation and nitrogen fertilization using a continuous variable design. Soil Sci. Soc. Amer. Proc. 39:1187-1192.

Bruce, R.R., J.L. Chesness, T.C. Keisling, J.E. Pallas, Jr., D.A. Smittle, J.R. Stansell, and A.W. Thomas. 1980. Irrigation of crops in the southeastern United States: Principles and practices. U.S. Dept. Agr. Agr. Rev. \& Man. ARM-S-9.

Haise, H.R. and R.M. Hagan. 1967. Soil, plant and evaporative measurements as criteria for scheduling irrigation, p. 577-604. In: R.M. Hagan, H.R. Haise, and T.W. Edminister (eds.). Irrigation of agricultural lands. Amer. Soc. Agron., Madison, Wis.

Hanks, R.J., J. Keller, V.P. Rasmussen, and G.D. Wilson. 1976. Line source sprinkler for continuous variable irrigation-crop production studies. Soil Sci. Soc. Amer. Proc. 40:426-429.

Hansen, V.E., O.W. Israelsen, and G.E. Stringham. 1980. Irrigation principles and practices. 4th ed. Wiley, New York.

Jensen, M.E. and J.E. Middleton. 1970. Scheduling irrigation from pan evaporation. Washington Agr. Expt. Sta. Circ. 527.

Plank, C.O. 1989. Soil test handbook for Georgia. Coop. Ext. Serv., Univ. of Georgia, Athens.

Portas, C.A.M. 1968. Development of root systems during the growth of some vegetable crops. Plant \& Soil 39:507-518.

SAS Institute. 1982. SAS users guide: Statistics. 1982 ed. SAS Institute, Cary, N.C.

Smittle, D.A., W.L. Dickens, and J.R. Stansell. 1990. An irrigation scheduling model for snap beans. J. Amer. Soc. Hort. Sci. 115:226230.

Smittle, D.A. and E.D. Threadgill. 1982. Response of squash to irrigation, nitrogen fertilization, and tillage systems. J. Amer. Soc. Hort. Sci. 107:437-440.

Smittle, D.A. and R.E. Williamson. 1977. Effect of soil compaction and nitrogen source on growth and yield of squash. J. Amer. Soc. Hort. Sci. 102:535-537.

Stansell, J.R. and D.A. Smittle. 1989. Effects of irrigation regimes on yield and water use of summer squash. J. Amer. Soc. Hort. Sci. 114:196-199.

Stegman, E.C., J.R. Musick, and J.I. Stewart. 1980. Irrigation water management, p. 763-816. In: M.E. Jensen (ed.). Design and operation of farm irrigation systems. Amer. Soc. Agr. Eng., St. Joseph, Mich.

Vittum, M.T. and W.J. Flocker. 1967. Vegetable crops, p. 674-686. In: R.M. Hagan, H.R. Haise, and T.W. Edminister (eds.). Irrigation of agricultural lands. Amer. Soc. Agron., Madison, Wis. 